\title{
SPORT CENTER UNIVERSITAS TANJUNGPURA
}

\author{
Muhammad Akrabbi Mahaghani' ${ }^{1}$ Tri Wibowo Caesariadi², Affrilyno ${ }^{3}$ \\ ${ }^{1}$ Mahasiswa, Program Studi Arsitektur, Fakultas Teknik, Universitas Tanjungpura \\ akrabbimahaghani86@gmail.com. \\ ${ }^{2}$ Program Studi Arsitektur, Fakultas Teknik, Universitas Tanjungpura \\ ${ }^{3}$ Program Studi Arsitektur, Fakultas Teknik, Universitas Tanjungpura
}

Naskah diajukan pada: 31 Januari 2021

Naskah revisi akhir diterima pada: 4 Februari 2021

\begin{abstract}
Abstrak
Olahraga adalah kegiatan atau aktivitas yang dilakukan dengan tujuan mendapatkan kesehatan jasmani maupun rohani. Masyarakat Kota Pontianak khususnya civitas akademisi Universitas Tanjungpura sering sekali melakukan kegiatan olahraga. Terdapat berbagai cara mengembangkan aktivitas olahraga salah satunya menyediakan wadah yang dapat menampung kegiatan olahraga yaitu "Sport Center Universitas Tanjungpura" dengan tujuan sebagai tempat untuk pertandingan dan latihan. Menerapkan pendekatan arsitektur modern menghasilkan bangunan yang lebih menekankan fungsi, hubungan dengan lingkungan sekitar, kejujuran dalam penggunaan material, kesederhanaan. Metodologi perencanaan yang digunakan yaitu dengan cara mengumpulkan data melalui metode deskriptif. Metode ini menguraikan secara sistematis, menjelaskan secara faktual dan akurat mengenai fakta-fakta, sifat serta hubungan persyaratan desain dan ketentuan desain terhadap perencanaan dan perancangan. Berdasarkan persyaratan dan ketentuan desain yang nantinya akan ditelusuri mengenai data yang diperlukan. Data yang terkumpul akan dianalisis sehingga mendapatkan kesimpulan dan Batasan secara jelas mengenai perencanaan dan perancangan area Sport Center Universitas Tanjungpura secara bertahap dari masalah yang bersifat umum ke masalah yang bersifat detail. Metode pembahasan akan dilakukan dengan tahapan gagasan, tahapan identifikasi masalah, tahap pengumpulan data, tahap analisis data, tahap sintesis, dan tahap rancangan. Hasil dari perancangan tugas akhir penulis adalah sebuah bangunan gedung olahraga yang terdiri dari 2 lantai dengan massa bangunan dibagi menjadi 2 bagian, yaitu gedung latihan dan gedung pertandingan. Bangunan dirancang dengan menggunakan minipile sebagai pondasi, rangka beton bertulang sebagai struktur kolom dan balok, dan baja sebagai material rangka atap.
\end{abstract}

Kata-kata kunci: Olahraga, Sport Center, Modern.

\begin{abstract}
Sports are activity carried out with the aim of getting physical and spiritual health. People of Pontianak, especially academic's civitas at Tanjungpura University, often do sports activities. There are various ways to develop sports activities, one of which is providing a container that can accommodate sports activities, such as the "Sport Center of Tanjungpura University" with the aim of being a place for matches and training. By applying with a modern architectural approach can generate buildings that emphasize function, relations with the surrounding environment, honesty in the use of materials and simplicity. The planning method used in this report is by collecting data through descriptive methods. This method describes systematically, explains factually and accurately about the facts, nature and relationship of design requirements and design provisions to planning and design. Based on the terms and conditions of the design, which will be searched for the required data. The data collected will be analyzed in order to get clear conclusions and limitations regarding the planning and design of the Tanjungpura University Sport Center area in stages from general problems to detailed problems. The method of discussion will be carried out with the idea step, the problem identification step, the data collection step, the data analysis step, the synthesis step, and the design step. The result of the design of the author's final project is a sports building which consists of 2 floors with the building mass divided into 2 parts, namely the training building and the competition building. The building is designed using a minipile as the foundation, reinforced concrete frame as the column and beam structure, and steel as the roof frame material.
\end{abstract}

Keywords: Sport, Sport Center, Modern 


\section{Pendahuluan}

Olahraga merupakan suatu kegiatan yang dilakukan dengan tujuan untuk memelihara kesehatan jasmani. Kegiatan olahraga dalam perkembangannya terbagi menjadi olahraga prestasi, olahraga rekreasi, dan olahraga pendidikan (UU Sistem Keolahragaan Nasional, 2005). Olahraga prestasi merupakan kegiatan jasmani yang bertujuan untuk memperoleh kemenangan prestasi, baik di pertandingan tingkat regional, nasional, maupun internasional. Olahraga rekreasi merupakan kegiatan olah tubuh yang bertujuan untuk mendapatkan kesenangan atau relaksasi, dan olahraga pendidikan merupakan kegiatan pelatihan olahraga di dunia pendidikan untuk menciptakan atlet yang berprestasi. Ketiga jenis olahraga ini diharapkan menjadi suatu sistem kegiatan yang saling mendukung. Universitas Tanjungpura merupakan salah satu lembaga pendidikan tinggi di Kota Pontianak yang memiliki mahasiswa, tenaga pengajar dan tenaga pengurus yang biasa disebut dengan civitas akademika. Demi kemajuan Universitas Tanjungpura diperlukan civitas akademika yang sehat jasmani dan rohani yang bisa didapatkan dengan cara berolahraga.

Pada dasarnya perkembangan olahraga di Universitas Tanjungpura Pontianak dapat dikatakan berkembang, terlihat dari 32 klub olahraga yang ada di Universitas Tanjungpura. Pada saat ini kegiatan olahraga di Universitas Tanjungpura tidak diimbangi dengan fasilitas pendukung olahraga seperti tempat pelatihan, tempat kompetisi dan fasilitas pendukungnya. Seluruh kegiatan tersebut belum memiliki pusat fasilitas, karena pada umumnya setiap fakultas yang berada di Universitas Tanjungpura memiliki wadah masing-masing sehingga sangat sulit untuk berkoordinasi secara langsung. Hal ini dapat diantisipasi jika Universitas Tanjungpura memiliki fasilitas yang dapat mewadahi seluruh kegiatan olahraga yang berupa sport center.

Perancangan Sport Center Universitas Tanjungpura bertujuan untuk dapat memaparkan penataan ruang yang efektif sehingga dapat mewadahi dan menunjang aktivitas olahraga civitas akademika Universitas Tanjugpura dan masyarakat sekitar dengan pendekatan arsitektur modern.

\section{Kajian Pustaka}

Mahasiswa memiliki banyak pekerjaan baik di kampus ataupun di luar kampus yang dapat menyebabkan stres pada mahasiswa. Stres pada mahasiswa dapat mengganggu kegiatan belajar yang menyebabkan penurunan nilai akademik. Menurut Septiani (2016), stres bisa terjadi pada siapapun termasuk pada mahasiswa. Stres pada mahasiswa bisa disebabkan ketidakmampuan dalam melakukan kewajibannya sebagai mahasiswa atau karena permasalahn lain. Untuk menurunkan tingkat stres dapat melakukan berbagai cara salah satunya berolahraga. Menurut Singh (2011), seorang periset dari Vrije Universiteit University Medical Center di Amsterdam, Belanda sekaligus penulis di Archieves of Pediatrics \& Adolescent Medicine, menyatakan bahwa, "Selain efek fisik, olahraga juga dapat membantu tingkah dan pola perilaku keseharian anak di kelas sehingga mereka lebih bisa berkonsentrasi saat belajar." Pasalnya selain memperlancar aliran darah ke otak, olahraga juga sekaligus memicu otak untuk melepaskan hormon mood bahagia endorfin, yang membuat emosi anak menjadi lebih mudah bahagia, stabil, dan tenang sehingga jadi jarang "berulah". Dengan berolahraga dapat menjadikan seseorang lebih semangat bekerja, fokus lebih baik, meningkatkan motivasi diri, manajemen stress lebih baik, dan membuat lebih aktif. Olahraga yang sering dilakukan mahasiswa biasanya berupa olahraga rekreasi seperti futsal, voli, basket, dan bulutangkis. Olahraga tersebut merupakan olahraga berkelompok sehingga lebih mengandalkan komunikasi antara pemain yang dapat meningkatkan sensor motorik antara pemain.

Pada Peraturan Menteri Riset, Teknologi, dan Pendidikan Tinggi Republik Indonesia Nomor 44 Tahun 2015 Bab VII Pasal 32 Ayat 1, menyebutkan bahwa "Standar sarana pembelajaran sebagaimana dalam Pasal 31 paling sedikit terdiri atas: (a) perabot; (b) peralatan pendidikan; (c) 
media pendidikan; (d) buku, buku elektronik, dan repositori; (e) sarana teknologi informasi dan komunikasi; (f) instrumentasi eksperimen; (g) sarana olahraga; (h) sarana berkesenian; (i) sarana fasilitas umum; (j) bahan habis pakai; dan (k) sarana pemeliharaan, keselamatan, dan keamanan." Selain itu, pada Pasal 33 ayat 1, juga menyebutkan bahwa, "Standar prasaran pembeljaran sebagaimana dimaksud dalam Pasal 31 paling sedikit terdiri atas: (a) lahan; (b) ruang kelas; (c) perpustakaan; (d) laboratorium/studio/bengkel kerja/unit produksi; (e) tempat berolahraga; (f) ruang untuk berkesenian; (g) ruang unit kegiatan mahasiswa; (h) ruang pimpinan perguruan tinggi; (i) ruang dosen; ( $\mathrm{j}$ ) ruang tata usaha; dan (k) fasilitas umum." Hal ini makin mempertegas akan kebutuhan sebuah sport center di lingkungan Universitas Tanjungpura.

Sport center adalah bangunan yang mewadahi berbagai olahraga di dalam ruangan tertutup maupun terbuka. Pada negara-negara maju sarana dan prasarana yang dimiliki oleh mereka juga memasukkan unsur-unsur pendukung seperti sarana rekreasi, sarana perdagangan (retail), dan restoran. Dalam buku Perrin (1981) yang berjudul "Design for Sport" dijelaskan bahwa sport center adalah suatu area dengan luasan tertentu yang bertujuan untuk mewadahi kegiatan berolahraga, berupa kegiatan latihan, rekreasi, maupun kompetitif. Sport center tersebut digabungkan dengan satu sport hall yang terdapat fasilitas lainnya untuk digunakan masyarakat.

Arsitektur modern adalah suatu bangunan dengan gaya karakteristik serupa yang mengutamakan kesederhanaan bentuk dan menghapus segala macam ornamen. Menurut Banham (1978) dalam bukunya yang berjudul "Age of the Master: A Personal view of Modern Architecture", perkembangan arsitektur modern menekankan pada kesederhanaan suatu desain dengan menganut Form Follows Function (bentuk mengikuti fungsi). Arsitektur Modern timbul karena adanya kemajuan dalam bidang teknologi yang membuat manusia cenderung untuk sesuatu yang ekonomis. Arsitektur Modern pertama kali muncul pada tahun 1900, pada tahun 1940 gaya ini telah diperkuat dan dikenal dengan gaya Internasional dan menjadi bangunan yang dominan dalam abad ke-20. Jadi, sport center dengan arsitektur modern adalah bangunan yang mewadahi berbagai olahraga di dalam ruangan tertutup maupun terbuka yang menekankan pada kesederhanaan suatu desain dan menghapus segala macam ornamen dengan menganut Form Follows Function (bentuk mengikuti fungsi).

Terdapat syarat dan ketentuan khusus dalam merancang suatu bangunan olahraga yang ditetapkan oleh instansi keolahragaan pemerintah. Sarana transportasi yang mendukung di lokasi, wadah parkir kendaraan yang maksimal, kontrol pada saat arus keluar manusia/penonton yang jelas agar terjadinya kerusuhan telah minimum, keterpaduan antara ruang dan fasilitas olahraga, serta keterkaitan dengan lingkungan merupakan pertimbangan utama dalam merancang suatu gedung olahraga.

\section{Metode}

Metode yang akan digunakan dalam penyusunan landasan konseptual arsitektur adalah metode deskriptif. Metode ini menguraikan secara sistematis, menjelaskan secara faktual dan akurat mengenai fakta-fakta, sifat serta hubungan persyaratan desain dan ketentuan desain terhadap perencanaan dan perancangan (Nazir, 1988). Berdasarkan persyaratan dan ketentuan desain yang nantinya akan ditelusuri mengenai data yang diperlukan. Data yang terkumpul akan dianalisis sehingga mendapatkan kesimpulan dan Batasan secara jelas mengenai perencanaan dan perancangan area Sport Center Universitas Tanjungpura secara bertahap dari masalah yang bersifat umum ke masalah yang bersifat detail. Metode pembahasan akan dilakukan dengan tahapan gagasan, tahapan identifikasi masalah, tahap pengumpulan data, tahap analisis data, tahap sintesis, dan tahap rancangan (Jones, 1992). 


\section{Hasil dan Pembahasan}

\section{Lokasi Perancangan}

Lokasi perancangan akan berada di Jalan Tanjung Sari, Kelurahan Bansir Laut, Kecamatan Pontianak Tenggara yang merupakan kawasan olahraga Universitas Tanjungpura, tepatnya di bagian barat Stadion Sepak Bola Universitas Tanjungpura. Pemilihan lokasi ini berdasarkan pertimbangan tata guna lahan Universitas Tanjungpura. Pertimbangan lainnya yaitu lokasi berada dekat dengan jalan utama (Jalan Daya Nasional), dekat dengan bangunan fasilitas Unit Kegiatan Mahasiswa (UKM), bangunan fasilitas umum dan letaknya yang stategis di antara tempat perkuliahan.

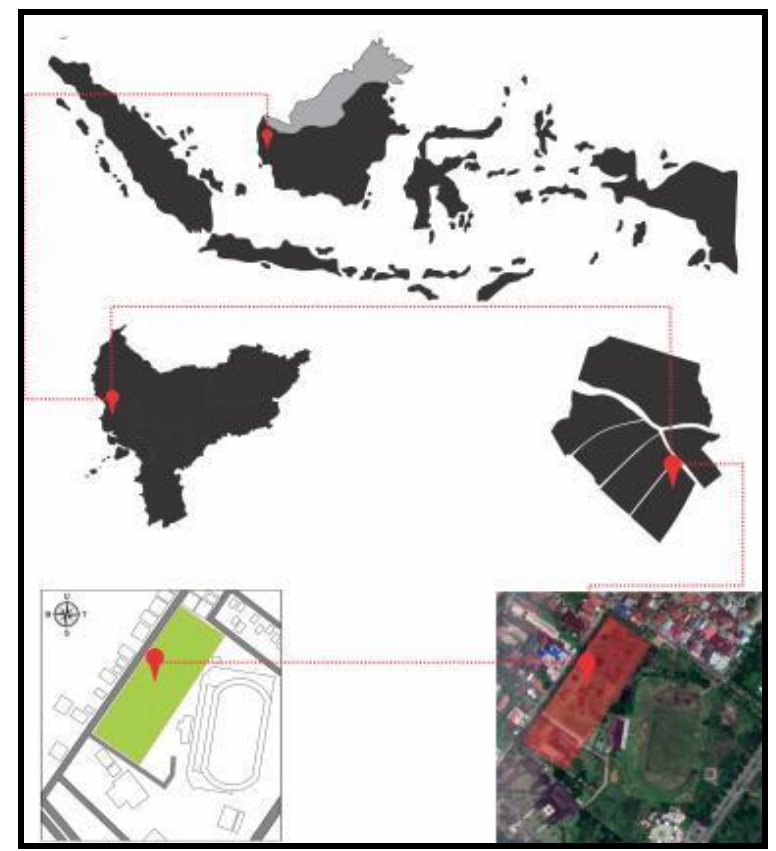

Gambar 1. Lokasi Perancangan Sport Center Universitas Tanjungpura Sumber: Penulis, 2020

\section{Fungsi}

Konsep fungsi pada Sport Center Universitas Tanjungpura terbagi menjadi dua yaitu fungsi utama dan fungsi penunjang. Fungsi utama meliputi fungsi sarana olahraga kompetisi sebagai penyediaan tempat untuk melakukan pelatihan untuk para atlet yang ada di Universitas Tanjungpura dan menjadi tempat penyelenggaraan pertandingan dengan ketentuan standar yang ada, serta sarana olahraga rekreasi sebagai tempat untuk kegiatan olahraga yang bertujuan untuk mendapat kesenangan dan kesehatan yang bersifat lebih santai.. Sedangkan untuk fungsi penunjang sebagai tempat bersosialisasi, tempat membeli peralatan olahraga, dan tempat pembelajaran untuk orang yang baru ingin menekuni kegiatan olahraga.

\section{Ide Perancangan}

Konsep ide dalam perancangan Sport Center Universitas Tanjungpura adalah untuk merancang sebuah fasilitas olahraga yang memberikan pelayanan secara langsung kepada civitas akademika untan maupun masyarakat sekitar untuk melakukan kegiatan olahraga, bersantai maupun bersosialisasi. Diharapkan dapat menjadi wadah yang sebagai pembibitan atlet muda berbakat sehingga dapat memajukan aktivitas olahraga di Kota Pontianak, Kalimantan Barat.

\section{Konsep Internal}

Konsep internal di dalam perancangan Sport Center Universitas Tanjungpura dapat dilihat pada Tabel 1 berikut. 
Tabel 1. Kompilasi Konsep Persyaratan Ruang Sport Center Universitas Tanjungpura

\begin{tabular}{|c|c|c|c|c|c|c|c|c|c|}
\hline \multirow{3}{*}{$\begin{array}{l}\text { Nama } \\
\text { Ruang }\end{array}$} & \multirow{3}{*}{$\begin{array}{c}\text { Sifat } \\
\text { Ruang }\end{array}$} & \multicolumn{8}{|c|}{ Persyaratan Ruang } \\
\hline & & \multicolumn{3}{|c|}{ Pencahayaan } & \multicolumn{3}{|c|}{ Penghawaan } & \multirow{2}{*}{$\begin{array}{c}\text { Akusti } \\
\text { ka } \\
(\mathbf{d B}) \\
\end{array}$} & \multirow[t]{2}{*}{ Akses } \\
\hline & & Lux & Alami & Buatan & $\begin{array}{c}\text { Temp } \\
\text { Co }^{\circ}\end{array}$ & Alami & Buatan & & \\
\hline Lobby & Publik & 200 & $\sqrt{ }$ & $\sqrt{ }$ & $27-29$ & $\sqrt{ }$ & $\sqrt{ }$ & $50-55$ & Langsung \\
\hline Ruang Loket & Publik & 200 & $\sqrt{ }$ & $\sqrt{ }$ & $27-29$ & $\sqrt{ }$ & $\sqrt{ }$ & $40-45$ & Langsung \\
\hline Jogging track & Publik & 200 & $\sqrt{ }$ & $\sqrt{ }$ & $\geq 29$ & $\sqrt{ }$ & & $60-90$ & Langsung \\
\hline $\begin{array}{l}\text { Lapangan } \\
\text { Pertandingan }\end{array}$ & $\begin{array}{c}\text { Semi } \\
\text { Publik }\end{array}$ & 400 & & $\sqrt{ }$ & $27-29$ & & $\sqrt{ }$ & $45-50$ & Langsung \\
\hline $\begin{array}{l}\text { Lapangan } \\
\text { Basket }\end{array}$ & $\begin{array}{c}\text { Semi } \\
\text { Publik }\end{array}$ & 200 & $\sqrt{ }$ & $\sqrt{ }$ & $27-29$ & & $\sqrt{ }$ & $45-50$ & Langsung \\
\hline $\begin{array}{l}\text { Lapangan } \\
\text { Voli }\end{array}$ & $\begin{array}{c}\text { Semi } \\
\text { Publik }\end{array}$ & 200 & $\sqrt{ }$ & $\sqrt{ }$ & $27-29$ & & $\sqrt{ }$ & $45-50$ & Langsung \\
\hline $\begin{array}{l}\text { Lapangan } \\
\text { Futsal }\end{array}$ & $\begin{array}{c}\text { Semi } \\
\text { Publik }\end{array}$ & 200 & $\sqrt{ }$ & $\sqrt{ }$ & $27-29$ & & $\sqrt{ }$ & $45-50$ & Langsung \\
\hline $\begin{array}{l}\text { Lapangan } \\
\text { Bulutangkis }\end{array}$ & $\begin{array}{c}\text { Semi } \\
\text { Publik }\end{array}$ & 200 & $\sqrt{ }$ & $\sqrt{ }$ & $27-29$ & & $\sqrt{ }$ & $45-50$ & Langsung \\
\hline $\begin{array}{l}\text { Latihan } \\
\text { Beladiri }\end{array}$ & $\begin{array}{c}\text { Semi } \\
\text { Publik }\end{array}$ & 200 & $\sqrt{ }$ & $\sqrt{ }$ & $27-29$ & & $\sqrt{ }$ & $45-50$ & Langsung \\
\hline $\begin{array}{l}\text { Fitness } \\
\text { Center }\end{array}$ & $\begin{array}{c}\text { Semi } \\
\text { Publik }\end{array}$ & 200 & $\sqrt{ }$ & $\sqrt{ }$ & $27-29$ & $\sqrt{ }$ & $\sqrt{ }$ & $45-50$ & Langsung \\
\hline $\begin{array}{l}\text { Tribun } \\
\text { Penonton } \\
\text { Umum }\end{array}$ & $\begin{array}{c}\text { Semi } \\
\text { Publik }\end{array}$ & 300 & $\sqrt{ }$ & $\sqrt{ }$ & $27-29$ & & $\sqrt{ }$ & $45-50$ & Langsung \\
\hline $\begin{array}{l}\text { Tribun } \\
\text { Penonton } \\
\text { VIP }\end{array}$ & $\begin{array}{l}\text { Semi } \\
\text { Privat }\end{array}$ & 300 & $\sqrt{ }$ & $\sqrt{ }$ & $27-29$ & & $\sqrt{ }$ & $45-50$ & Langsung \\
\hline $\begin{array}{l}\text { Ruang } \\
\text { Pemanasan }\end{array}$ & Privat & 200 & $\sqrt{ }$ & $\sqrt{ }$ & $27-29$ & & $\sqrt{ }$ & $45-50$ & $\begin{array}{c}\text { Tidak } \\
\text { Langsung }\end{array}$ \\
\hline Ruang Bilas & Privat & 200 & & $\sqrt{ }$ & $27-29$ & & $\sqrt{ }$ & $40-45$ & $\begin{array}{c}\text { Tidak } \\
\text { Langsung }\end{array}$ \\
\hline Ruang Ganti & Privat & 200 & & $\sqrt{ }$ & $27-29$ & & $\sqrt{ }$ & $60-90$ & $\begin{array}{c}\text { Tidak } \\
\text { Langsung }\end{array}$ \\
\hline
\end{tabular}




\begin{tabular}{|c|c|c|c|c|c|c|c|c|}
\hline Ruang Loker & Privat & 200 & $\sqrt{ }$ & $\sqrt{ }$ & $27-29$ & $\sqrt{ }$ & $40-45$ & $\begin{array}{c}\text { Tidak } \\
\text { Langsung }\end{array}$ \\
\hline Ruang P3K & Privat & 300 & & $\sqrt{ }$ & $27-29$ & $\sqrt{ }$ & $40-45$ & $\begin{array}{c}\text { Tidak } \\
\text { Langsung }\end{array}$ \\
\hline Ruang Pijat & Privat & 200 & & $\sqrt{ }$ & $27-29$ & $\sqrt{ }$ & $40-45$ & $\begin{array}{c}\text { Tidak } \\
\text { Langsung }\end{array}$ \\
\hline $\begin{array}{l}\text { Ruang } \\
\text { Latihan } \\
\text { Beban }\end{array}$ & Privat & 200 & $\sqrt{ }$ & $\sqrt{ }$ & $27-29$ & $\sqrt{ }$ & $45-50$ & $\begin{array}{c}\text { Tidak } \\
\text { Langsung }\end{array}$ \\
\hline $\begin{array}{l}\text { Ruang Media } \\
\text { dan Reporter }\end{array}$ & Privat & 200 & $\sqrt{ }$ & $\sqrt{ }$ & $24-27$ & $\sqrt{ }$ & $40-45$ & $\begin{array}{c}\text { Tidak } \\
\text { Langsung }\end{array}$ \\
\hline $\begin{array}{l}\text { Ruang } \\
\text { Konferensi }\end{array}$ & $\begin{array}{l}\text { Semi } \\
\text { Privat }\end{array}$ & 200 & & $\sqrt{ }$ & $24-27$ & $\sqrt{ }$ & $30-40$ & $\begin{array}{c}\text { Tidak } \\
\text { Langsung }\end{array}$ \\
\hline Ruang VIP & Privat & 300 & & $\sqrt{ }$ & $24-27$ & $\sqrt{ }$ & $40-45$ & $\begin{array}{c}\text { Tidak } \\
\text { Langsung }\end{array}$ \\
\hline $\begin{array}{l}\text { Ruang } \\
\text { Pelatih }\end{array}$ & Privat & 200 & & $\sqrt{ }$ & $24-27$ & $\sqrt{ }$ & $40-45$ & $\begin{array}{c}\text { Tidak } \\
\text { Langsung }\end{array}$ \\
\hline Ruang Wasit & Privat & 200 & & $\sqrt{ }$ & $24-27$ & $\sqrt{ }$ & $40-45$ & $\begin{array}{c}\text { Tidak } \\
\text { Langsung }\end{array}$ \\
\hline $\begin{array}{l}\text { Ruang } \\
\text { Peserta }\end{array}$ & Privat & 200 & & $\sqrt{ }$ & $24-27$ & $\sqrt{ }$ & $40-45$ & $\begin{array}{c}\text { Tidak } \\
\text { Langsung }\end{array}$ \\
\hline Gudang Alat & $\begin{array}{l}\text { Semi } \\
\text { Privat }\end{array}$ & 150 & $\sqrt{ }$ & & $27-29$ & $\sqrt{ }$ & $40-60$ & $\begin{array}{c}\text { Tidak } \\
\text { Langsung }\end{array}$ \\
\hline Lavatory & Servis & 200 & & $\sqrt{ }$ & $24-27$ & $\sqrt{ }$ & $45-50$ & Langsung \\
\hline $\begin{array}{l}\text { UKM } \\
\text { Universitas } \\
\text { Tanjungpura }\end{array}$ & Privat & 200 & $\sqrt{ }$ & $\sqrt{ }$ & $24-27$ & $\sqrt{ }$ & $40-45$ & Langsung \\
\hline $\begin{array}{l}\text { Ruang } \\
\text { Informasi }\end{array}$ & Publik & 200 & $\sqrt{ }$ & $\sqrt{ }$ & $24-27$ & $\sqrt{ }$ & $40-45$ & Langsung \\
\hline $\begin{array}{l}\text { Ruang } \\
\text { Pelayanan }\end{array}$ & Publik & 200 & $\sqrt{ }$ & $\sqrt{ }$ & $24-27$ & $\sqrt{ }$ & $40-45$ & Langsung \\
\hline $\begin{array}{l}\text { Ruang Ketua } \\
\text { Sport Center }\end{array}$ & Privat & 200 & & $\sqrt{ }$ & $24-27$ & $\sqrt{ }$ & $40-45$ & $\begin{array}{c}\text { Tidak } \\
\text { Langsung }\end{array}$ \\
\hline $\begin{array}{l}\text { Ruang } \\
\text { Seketaris }\end{array}$ & Privat & 200 & & $\sqrt{ }$ & $24-27$ & $\sqrt{ }$ & $40-45$ & $\begin{array}{c}\text { Tidak } \\
\text { Langsung }\end{array}$ \\
\hline
\end{tabular}




\begin{tabular}{|c|c|c|c|c|c|c|c|c|c|}
\hline $\begin{array}{l}\text { Ruang } \\
\text { Bendahara }\end{array}$ & Privat & 200 & & $\sqrt{ }$ & $24-27$ & & $\sqrt{ }$ & $40-45$ & $\begin{array}{c}\text { Tidak } \\
\text { Langsung }\end{array}$ \\
\hline $\begin{array}{l}\text { Ruang Kerja } \\
\text { Staff }\end{array}$ & Privat & 200 & & $\sqrt{ }$ & $24-27$ & & $\sqrt{ }$ & $40-45$ & $\begin{array}{c}\text { Tidak } \\
\text { Langsung }\end{array}$ \\
\hline Ruang Arsip & Privat & 200 & & $\sqrt{ }$ & $24-27$ & & $\sqrt{ }$ & $35-45$ & $\begin{array}{c}\text { Tidak } \\
\text { Langsung }\end{array}$ \\
\hline Ruang Rapat & Privat & 200 & & $\sqrt{ }$ & $24-27$ & & $\sqrt{ }$ & $45-50$ & $\begin{array}{c}\text { Tidak } \\
\text { Langsung }\end{array}$ \\
\hline $\begin{array}{l}\text { Ruang Ganti } \\
\text { dan Loker }\end{array}$ & Privat & 200 & & $\sqrt{ }$ & $24-27$ & & $\sqrt{ }$ & $60-90$ & $\begin{array}{c}\text { Tidak } \\
\text { Langsung }\end{array}$ \\
\hline $\begin{array}{l}\text { Ruang } \\
\text { Security }\end{array}$ & Privat & 200 & $\sqrt{ }$ & $\sqrt{ }$ & $24-27$ & $\sqrt{ }$ & $\sqrt{ }$ & $30-50$ & $\begin{array}{c}\text { Tidak } \\
\text { Langsung }\end{array}$ \\
\hline $\begin{array}{l}\text { Ruang } \\
\text { CCTV }\end{array}$ & Privat & 200 & & $\sqrt{ }$ & $24-27$ & & $\sqrt{ }$ & $40-60$ & $\begin{array}{c}\text { Tidak } \\
\text { Langsung }\end{array}$ \\
\hline Ruang AHU & Servis & 200 & & $\sqrt{ }$ & $27-29$ & & $\sqrt{ }$ & $40-60$ & Langsung \\
\hline $\begin{array}{l}\text { Ruang } \\
\text { Mekanikal }\end{array}$ & Servis & 200 & & $\sqrt{ }$ & $27-29$ & & $\sqrt{ }$ & $60-90$ & Langsung \\
\hline Ruang Panel & Servis & 200 & & $\sqrt{ }$ & $27-29$ & & $\sqrt{ }$ & $60-90$ & Langsung \\
\hline $\begin{array}{l}\text { Ruang Sound } \\
\text { sistem }\end{array}$ & Servis & 200 & & $\sqrt{ }$ & $27-29$ & & $\sqrt{ }$ & $40-60$ & Langsung \\
\hline $\begin{array}{l}\text { Ruang } \\
\text { Pompa }\end{array}$ & Servis & 200 & & $\sqrt{ }$ & $27-29$ & & $\sqrt{ }$ & $60-90$ & Langsung \\
\hline $\begin{array}{l}\text { Ruang } \\
\text { Genset }\end{array}$ & Servis & 200 & & $\sqrt{ }$ & $27-29$ & & $\sqrt{ }$ & $60-90$ & Langsung \\
\hline $\begin{array}{l}\text { Ruang } \\
\text { Chiller }\end{array}$ & Servis & 200 & & $\sqrt{ }$ & $27-29$ & & $\sqrt{ }$ & $60-90$ & Langsung \\
\hline $\begin{array}{l}\text { Ruang } \\
\text { Janitor }\end{array}$ & Servis & 100 & & $\sqrt{ }$ & $27-29$ & & $\sqrt{ }$ & $30-40$ & Langsung \\
\hline $\begin{array}{l}\text { Ruang } \\
\text { Pembuangan } \\
\text { Sampah }\end{array}$ & Servis & 200 & $\sqrt{ }$ & $\sqrt{ }$ & $27-29$ & $\sqrt{ }$ & & $60-70$ & Langsung \\
\hline Mushola & Servis & 200 & $\sqrt{ }$ & $\sqrt{ }$ & $24-27$ & $\sqrt{ }$ & $\sqrt{ }$ & $45-50$ & Langsung \\
\hline Lavatory & Servis & 200 & & $\sqrt{ }$ & $24-27$ & & $\sqrt{ }$ & $45-50$ & Langsung \\
\hline Coffee Shop & Publik & 300 & $\sqrt{ }$ & $\sqrt{ }$ & $27-29$ & $\sqrt{ }$ & $\sqrt{ }$ & $45-50$ & Langsung \\
\hline
\end{tabular}




\begin{tabular}{llllllllll}
\hline Restaurant & Publik & 300 & $\sqrt{ }$ & $\sqrt{ }$ & $27-29$ & $\sqrt{ }$ & $\sqrt{ }$ & $40-60$ & Langsung \\
\hline Retail & Publik & 300 & $\sqrt{ }$ & $\sqrt{ }$ & $27-29$ & $\sqrt{ }$ & $\sqrt{ }$ & $40-55$ & Langsung \\
\hline $\begin{array}{l}\text { Loading } \\
\text { Dock }\end{array}$ & Publik & 100 & $\sqrt{ }$ & $\sqrt{ }$ & $27-29$ & $\sqrt{ }$ & $\sqrt{ }$ & $55-65$ & Langsung \\
\hline Mushola & Servis & 200 & $\sqrt{ }$ & $\sqrt{ }$ & $24-27$ & $\sqrt{ }$ & $\sqrt{ }$ & $45-50$ & Langsung \\
\hline Lavatory & Servis & 200 & & $\sqrt{ }$ & $24-27$ & & $\sqrt{ }$ & $45-50$ & Langsung \\
\hline
\end{tabular}

Sumber: Penulis, 2020

Tabel 2. Konsep Besaran Ruang Sport Center Universitas Tanjungpura

\section{Kebutuhan Fasilitas}

\begin{tabular}{lc}
\hline Fasilitas Olahraga & 5676,346 \\
\hline Fasilitas Pengunjung & 1720,238 \\
\hline Fasilitas Penunjang & 695,214 \\
\hline Fasilitas Komersil dan rekreasi & 555,75 \\
\hline Parkir Kendaraan & 2050,75 \\
\hline Total & 10698,298 \\
\hline
\end{tabular}

Sumber: Penulis, 2020

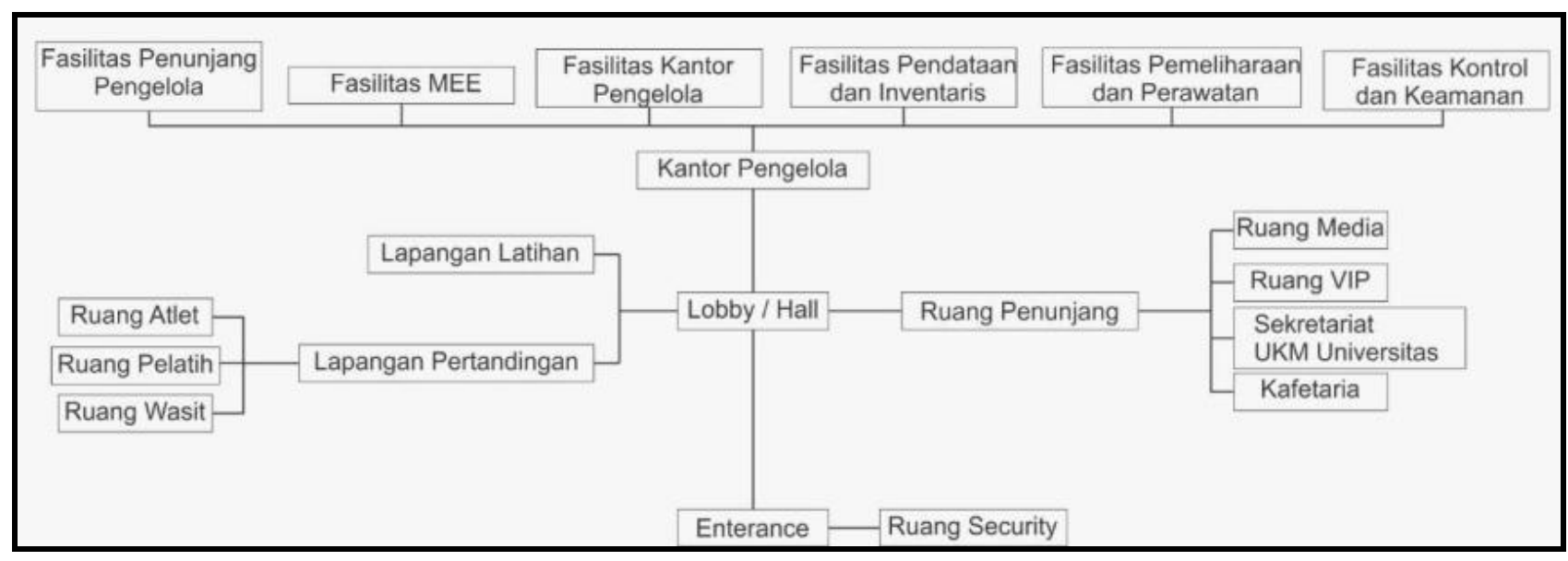

Gambar 2. Konsep Organisasi Ruang Sport Center Universitas Tanjungpura

Sumber: Penulis, 2020

\section{Konsep Tapak}

Konsep tapak didapat dari hasil analisis konsep orientasi, perletakan, sirkulasi, vegetasi dan zonasi. Hasil analisis orientasi pada perancangan Sport Center Universitas Tanjungpura ini ada tiga. Pertama, orientasi bangunan menghadap ke jalan utama yang ada di arah barat, kemudian orientasi kedua orientasi bangunan menghadap ke arah timur yang terdapat bangunan stadion dan yang terakhir orientasi menghadap ke arah selatan yang disana terdapat gedung auditorium. 


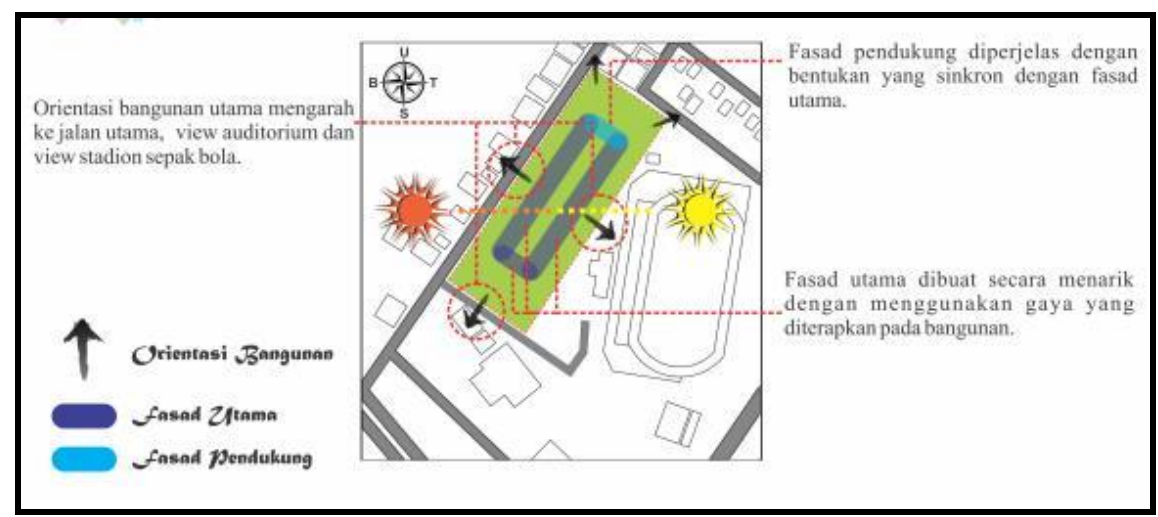

Gambar 3. Konsep Orientasi

Sumber: Penulis, 2020

Hasil analisis perletakkan ialah bangunan berada di tengah site dengan sedikit memberi jarak pada bagian barat menjauhi jalan utama dengan beberapa pertimbangan yaitu untuk keamanan dan penyediaan ruang parkir di depan bangunan. Kemudian ruang yang ada di arah timur juga untuk parkir pengelola dan angkutan atlet.

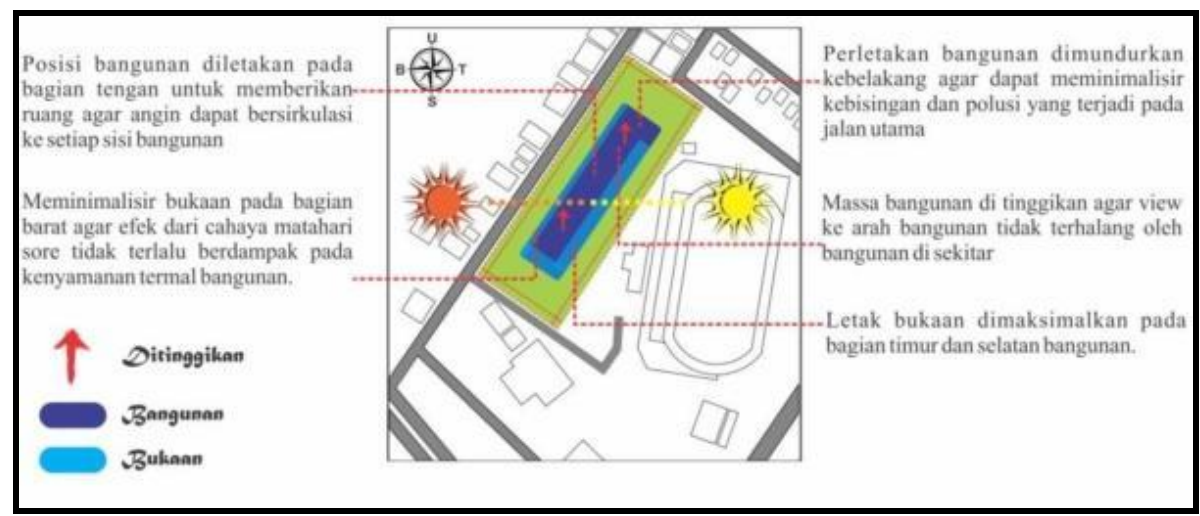

Gambar 4. Konsep Perletakan

Sumber: Penulis, 2020

Hasil analisis sirkulasi ialah untuk main entrance kendaraan berada pada Jalan Tanjung Sari. Untuk dropoff bangunan terdapat di sisi bangunan bagian barat yang berada tepat di jalan utama. Jalur keluar kendaraan dari kawasan berada pada arah selatan bangunan yang terdapat jalan lingkungan agar tidak terjadi penumpukan di jalan utama.

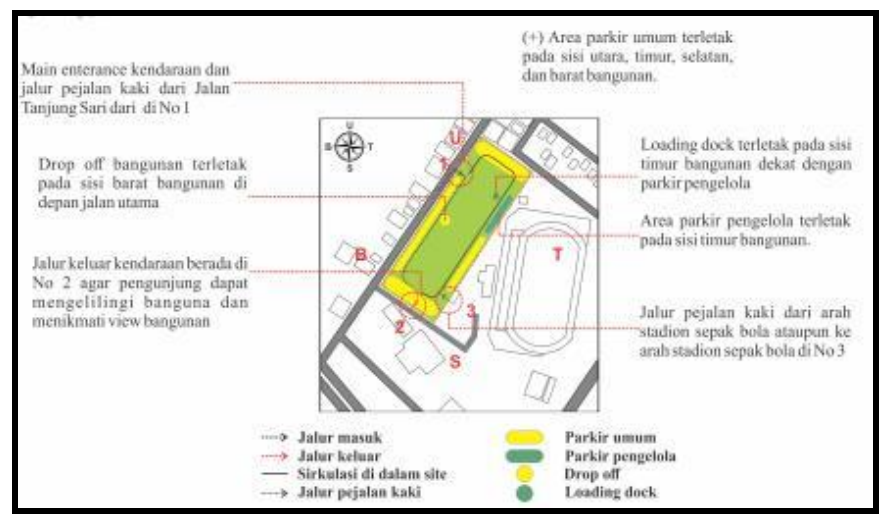

Gambar 5. Konsep Sirkulasi

Sumber: Penulis, 2020 
Sport Center Universitas Tanjungpura menggunakan beberapa jenis vegetasi, antara lain vegetasi peneduh, vegetasi estetis, vegetasi buffer, dan vegetasi pengarah. Vegetasi peneduh yang digunakan pada perancangan ini adalah Pohon Tanjung dan Pohon Kiara Payung. Untuk vegetasi estetis yang digunakan pada perancangan ini adalah Pohon Johar dan Bougenville. Lalu, pada perancangan ini menggunakan vegetasi buffer berupa Pohon Pucuk Merah dan Pohon Perdu. Terakhir, vegetasi pengarah yang diterapkan pada perancangan ini adalah Pohon Palm Raja. Vegetasi pengarah diletakkan di sekitar sirkulasi di dalam kawasan perancangan bangunana Sport Center Universitas Tanjungpura.

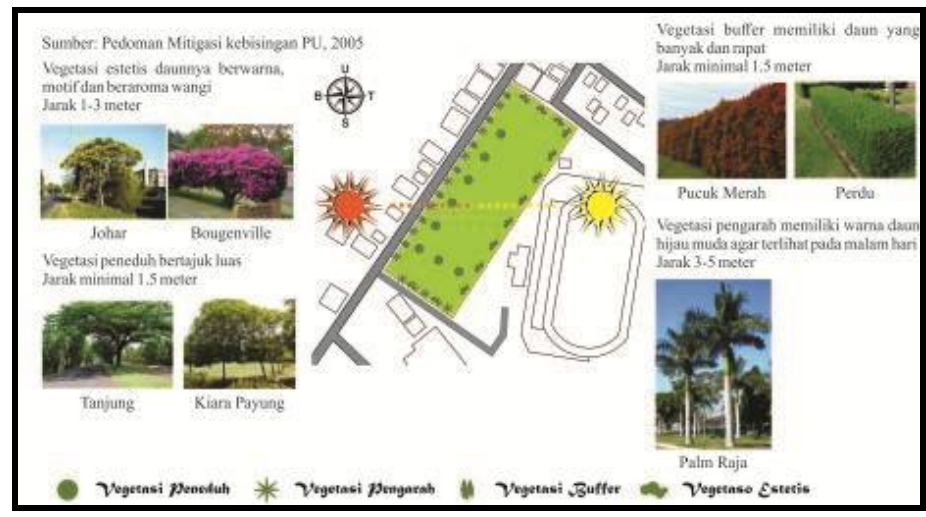

Gambar 6. Konsep Vegetasi

Sumber: Penulis, 2020

Zonasi untuk area publik (warna biru muda) berfungsi sebagai area yang dapat dikunjungi secara umum. Zona semi publik (warna biru tua) berfungsi sebagai zona yang dikunjungi secara umum dengan tujuan berolahraga ataupun menonton kegiatan olahraga. Zona semi privat (warna merah muda) hanya dapat dikunjungi dengan tujuan tertentu. Zona privat (warna merah) hanya dapat dikunjungi oleh orang tertentu. Zona servis (warna kuning) berfungsi sebagai pendukung dari zona lain atau zona untuk melayani seluruh zona yang ada di dalam bangunan.

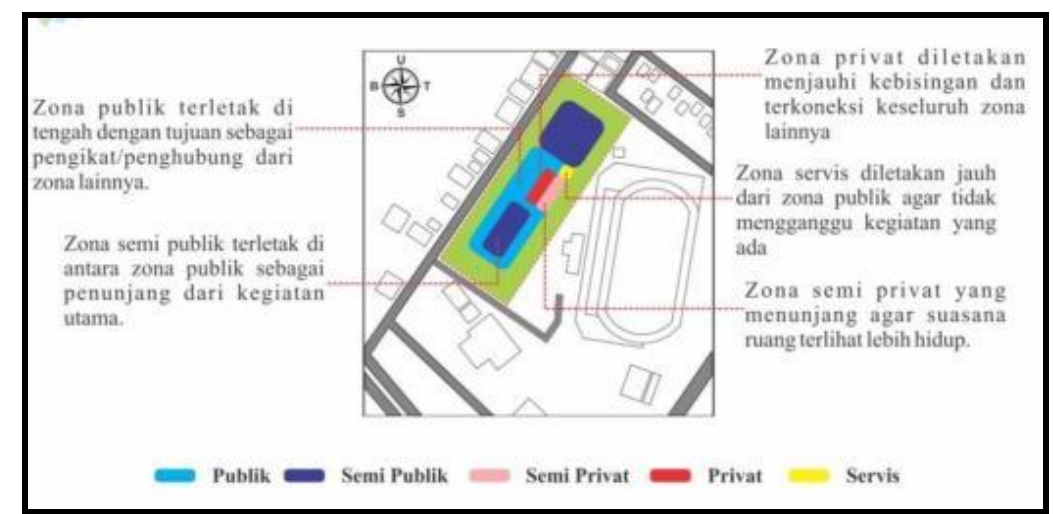

Gambar 7. Konsep Zonasi

Sumber: Penulis, 2020

\section{Konsep Fisika Bangunan}

Konsep fisika bangunan terbagi atas 3 bagian konsep, yaitu konsep pencahayaan, konsep penghawaan, serta konsep akustika. Untuk lapangan pertandingan menggunakan lampu sorot jenis Philips 1XHPi-TP400w untuk bagian tribun menggunakan lampu gantung jenis Philips TWC060 2XTL-D36W HF. Lalu, untuk konsep penghawaan pada bangunan sport center sebagian besar menggunakan penghawaan alami dengan memanfaatkan bukaan sebagai jalan masuknya udara ke dalam ruangan, seperti di beberapa ruang olahraga untuk latihan dan ruang olahraga untuk 
pertandingan. Untuk penghawaan buatan digunakan di ruang yang sifatnya lebih tertutup seperti ruang untuk pengelola. Selanjutnya, konsep akustika digunakan untuk meminimalisir kebisingan yang terjadi maka pada bangunan sport center ini menggunakan material kaca double glass.

\section{Konsep Struktur}

Konsep struktur terbagi menjadi dua jenis yaitu konsep struktur bawah dan atas. Struktur bawah meliputi struktur pondasi dan struktur atas meliputi struktur rangka, dinding, lantai dan atap. Berikut konsep struktur yang digunakan pada Sport Center Universitas Tanjungpura.

\section{A. Struktur Bawah}

Berdasarkan analisis pemilihan pondasi, pondasi yang digunakan yaitu pondasi tiang pancang beton. Ini dikarenakan efisien waktu, biaya, dan faktor transportasi sangat mendukung terpilihnya pondasi tiang pancang beton sebagai struktur bawah pada bangunan Sport Center Universitas Tanjungpura.

\section{B. Struktur Atas}

Berdasarkan hasil analisis struktur, konsep struktur rangka yang digunakan adalah struktur rangka beton bertulang. Penggunaan rangka beton bertulang digunakan karena bahan mudah didapat dan pengerjaan yang sudah sering dilakukan. Berdasarkan bentuk atap yang digunakan pada area olahraga maka konstruksi atap menggunakan baja dengan model barrel dengan finishing material penutup atap berupa zincalume karena material ini mudah dibentuk mengikuti pola rangka atap. Sedangkan pada area selain area olahraga menggunakan atap datar.

\section{Konsep Utilitas}

Konsep utilitas membahas sistem utilitas pada bangunan Sport Center Universitas Tanjungpura. Konsep utilitas yang dibahas adalah sistem air bersih, sanitasi dan drainase, jaringan listrik, keamanan terhadap kebakaran, tata udara, informasi dan komunikasi, dan keamanan bangunan. Konsep jaringan air bersih akan membahas sistem, besaran penampung air yang sesuai dengan kebutuhan. Pengadaan air bersih berasal dari Perusahaan Daerah Air Minum (PDAM). Sistem sanitasi dan drainase membahas sistem dan besaran penampung air kotor.

Alat pemadam api ringan (APAR), heat detector, smoke detector, dan sprinkler merupakan alat dari sistem keamanan kebakaran pada bangunan Sport Center Universitas Tanjungpura. Untuk sistem penyediaan listrik, aliran listrik yang digunakan berasal dari Perusahaan Listrik Negara (PLN) dan arus cadangan berasal dari generator listrik yang digunakan pada saat pemadaman listrik. Sistem komunikasi jaringan telepon menggunakan sistem IP-PABX, yaitu jaringan yang memanfaatkan Internet Protocol (IP). Instalasi tata suara menggunakan jaringan informasi yang bersifat public yaitu menggunakan mic dan speaker, dengan control yang diletakkan di ruang audio. Jaringan keamanan bangunan menggunakana Close Circuit Television (CCTV). Pada bangunan olahraga, penghawaan alami merupakan hal utama guna mendukung kegiatan berolahraga di dalamnya. Untuk sistem persampahan, sampah yang berasal dari sisa makanan/sampah (organik dan non organik) yang ditampung di bak penampungan sementara kemudian akan diangkut kendaraan pengangkut sampah menuju ke Tempat Pembuangan Akhir (TPA) secara berkala.

\section{Konsep Tata Ruang Luar}

Tata ruang luar Sport Center Universitas Tanjungpura dibagi menjadi beberapa area yaitu terdapat di bagian barat, selatan, timur, dan utara bangunan. Untuk sirkulasi kendaraan di dalam kawasan dapat dilihat dari garis berwarna kuning yang jalur entrance berada di Jalan Tanjung Sari dan kelur di jalan lingkungan. Untuk jalur entrance pejalan kaki dibagi menjadi dua yaitu yang berada di bagian barat bangunan dan di bagian timur bangunan. Jalur pejalan kaki dapat dilihat dari garis berwarna merah. 


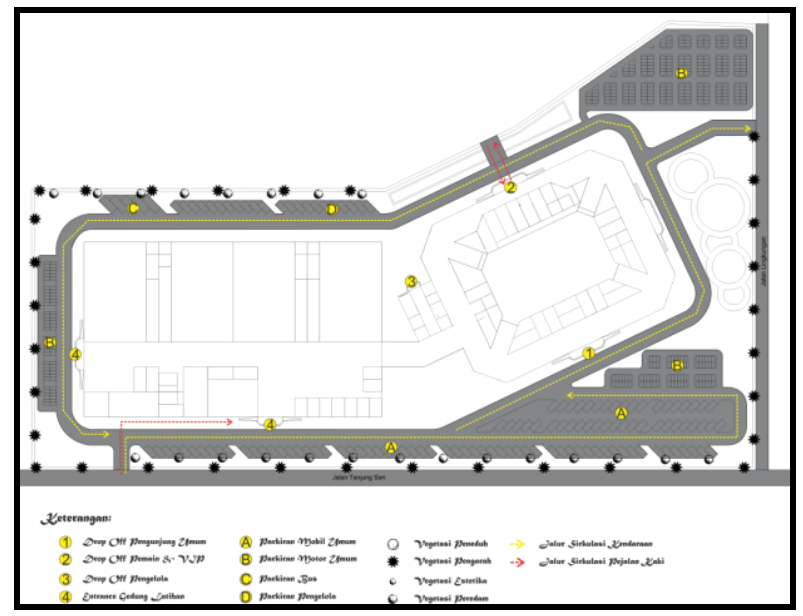

Gambar 8. Tata Ruang Luar Sport Center Universitas Tanjungpura

Sumber: Penulis, 2020

\section{Konsep Tata Ruang Dalam}

Tata ruang dalam pada Sport Center Universitas Tanjungpura disesuaikan dengan hasil yang didapatkan dari konsep internal. Bangunan terdiri dari dua lantai, maka tata ruang dalam yang dijabarkan hanya terdiri dari dua lantai.

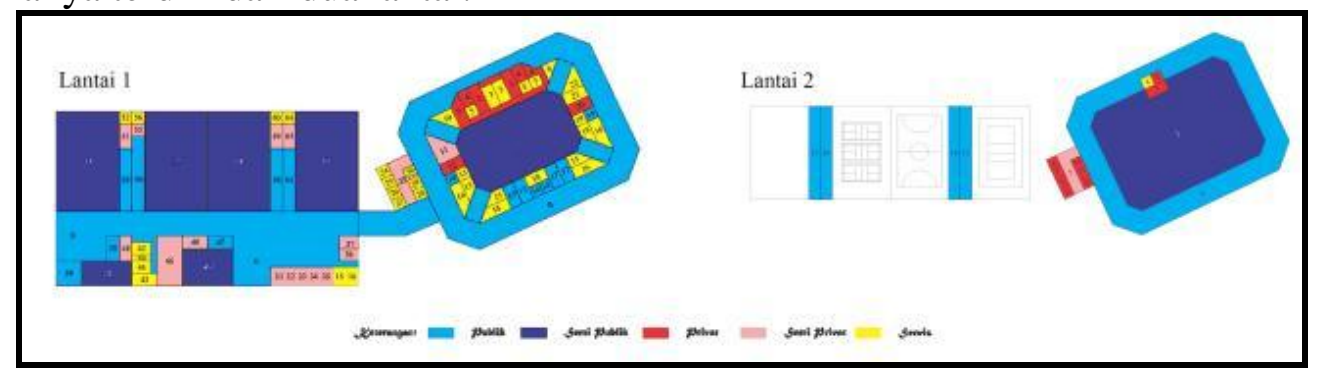

Gambar 9. Tata Ruang Dalam Lantai 1 Sport Center Universitas Tanjungpura Sumber: Penulis, 2020

\section{Gubahan Bentuk}

Gubahan bentuk pada perancangan ini diperoleh dari pertimbangan hasil analisa kondisi eksisting yang terdapat di sekitar site perancangan. Adapun tahapan-tahapan dari setiap perubahan bentuk dari perancangan dapat dilihat dari gambar di bawah ini.

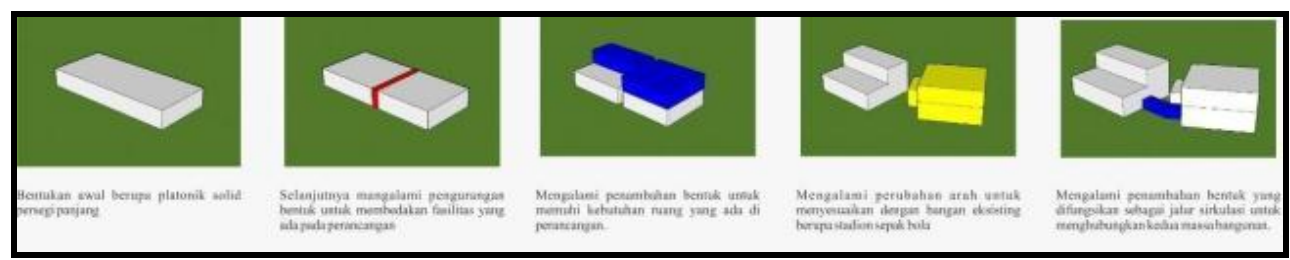

Gambar 10. Gubahan Bentuk Sport Center Universitas Tanjungpura Sumber: Penulis, 2020

\section{Siteplan}

Siteplan menggambarkan hubungan tata ruang dalam dengan tata ruang luar serta penataan terkait landscape bangunan. Siteplan Sport Center Universitas Tanjungpura dirancang sedemikian rupa dengan mempertimbangkan sirkulasi pada lokasi perancangan dan kenyamanan pengguna. 


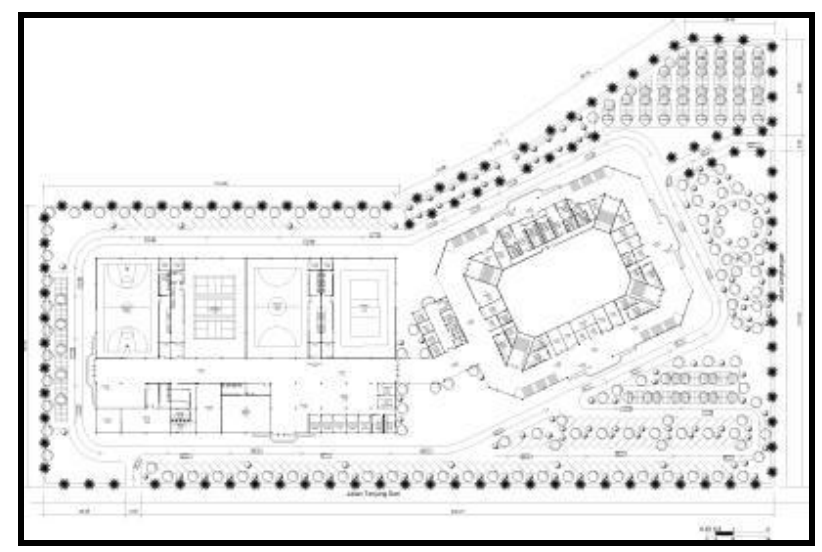

Gambar 11. Siteplan Sport Center Universitas Tanjungpura

Sumber: Penulis, 2020

\section{Denah}

Gambar denah lantai 1 menggambarkan tata ruang bangunana pada lantai 1 yang terdiri dari lobby, arena olahraga, lounge, retail dan sekretariat Unit Kegiatan Mahasiswa (UKM). Area servis diletakkan di area yang mudah diakses oleh pengguna fasilitas. Serta, gambar denah lantai 2 mnggambarkan tata ruang bangunan pada lantai 2 yang di fungsikan sebagai tribun arena olahraga. Pada lantai 2 juga terdapat area khusus pengelola seperti ruang kelapa pengelola, ruang seketaris, ruang bendahara, ruang arsip dan ruang rapat.

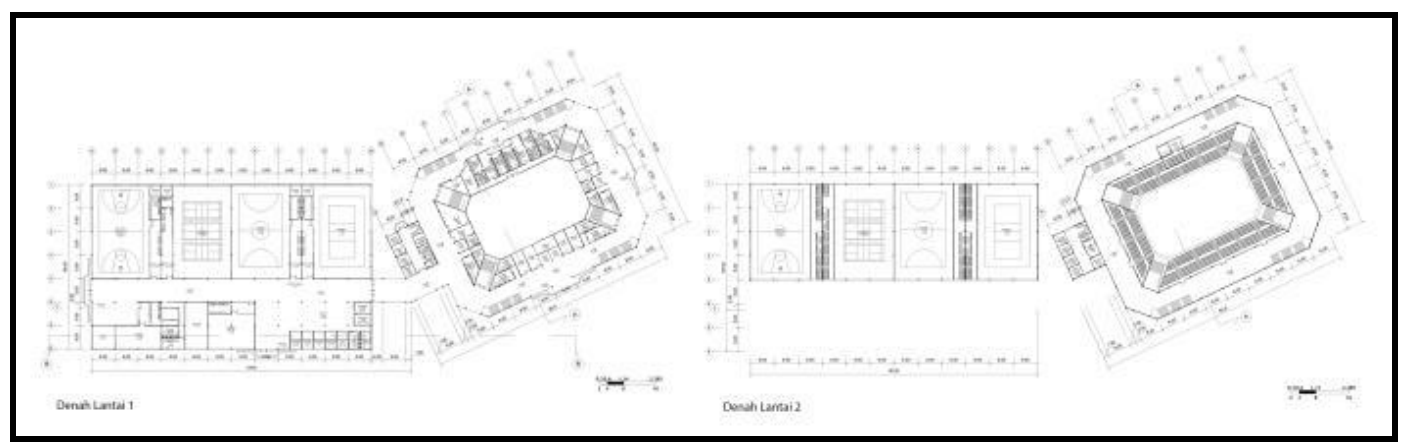

Gambar 12. Denah Sport Center Universitas Tanjungpura

Sumber: Penulis, 2020

\section{Tampak}

Tampak menjelaskan gambar tampak tiap sisi bangunan. Gambar tampak juga menggambarkan perbandingan skala terhadap lingkungan sekitarnya menggunakan parameter tinggi manusia, kendaraan, maupun pohon. Gambar tampak terdiri dari tampak depan, tampak samping kanan, tampak samping kiri, dan tampak belakang.

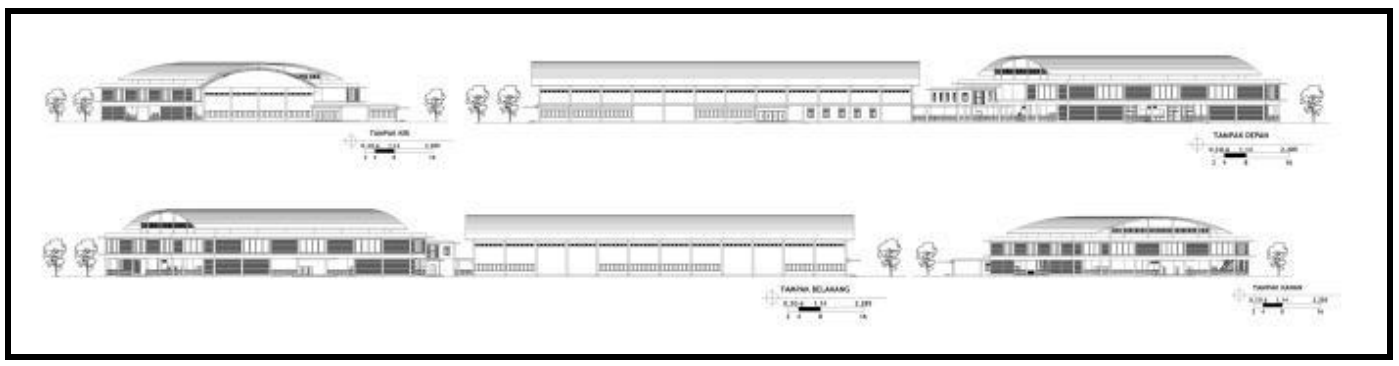

Gambar 13. Tampak Sport Center Universitas Tanjungpura

Sumber: Penulis, 2020 


\section{Potongan}

Gambar potongan menjelaskan potongan bangunan dari sisi ataupun arah tertentu. Gambar ini menjelaskan perancangan terkait material yang digunakan, ukuran, elevasi bangunan dan skala ruangan pada bagian yang terpotong. Potongan pada perancangan Sport Center Universitas Tanjungpura juga menunjukan sistem struktur pada bangunan. Bangunan menggunakan pondasi taing pancang mini pile. Menggunakan rangka beton bertulang dan rangka atap baja.

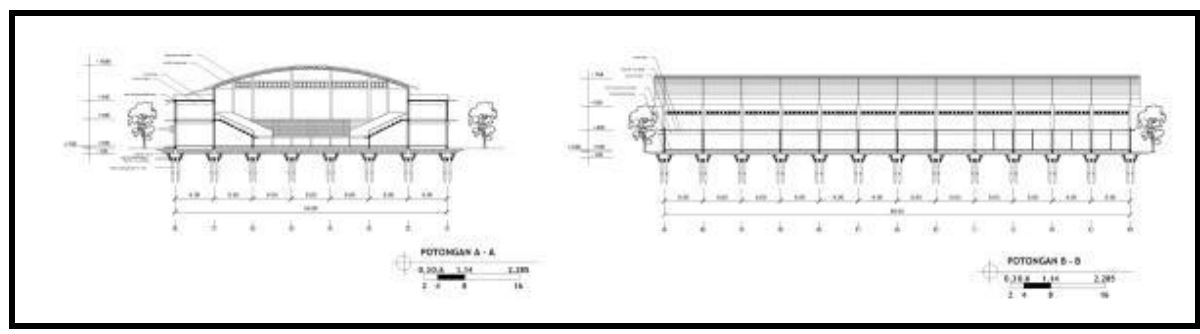

Gambar 14. Potongan Sport Center Universitas Tanjungpura Sumber: Penulis, 2020

\section{Suasana Ruang Luar dan Ruang Dalam}

Suasana luar bangunan menggambarkan kondisi bangunan pada bagian luar dengan menggunakan sudut pandang perspektif. Suasana luar memperlihatkan jensi material yang digunakan pada fasad bangunan dan lingkungan sekitar bangunan.

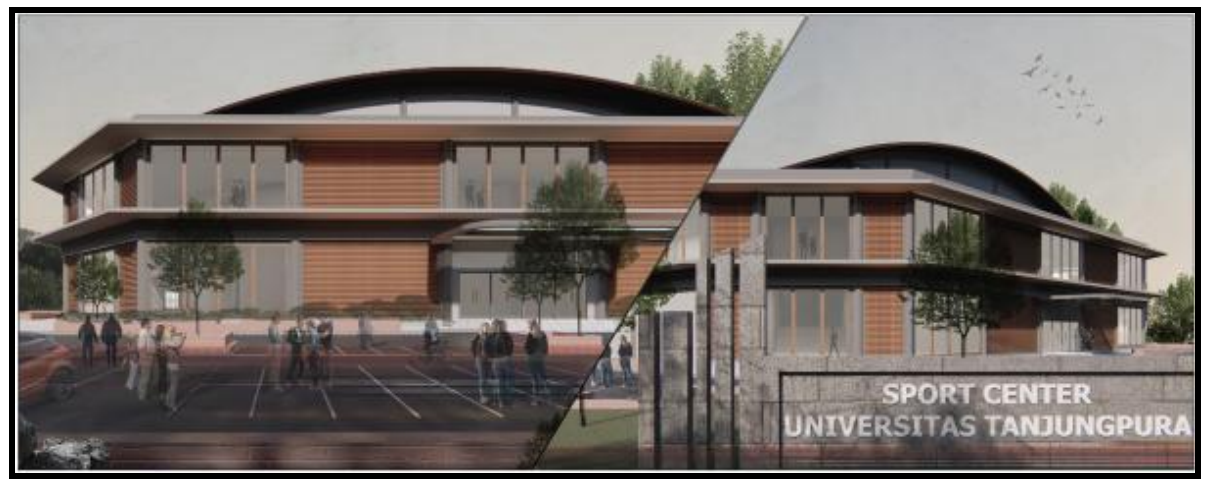

Gambar 15. Suasana Ruang Luar Sport Center Universitas Tanjungpura Sumber: Penulis, 2020

Suasana dalam bangunan menggambarkan kondisi bangunan pada bagian dalam dengan mengunakan sudut pandang perspektif. Suasana dalam memperlihatkan jenis material yang digunakan pada bangian dalam bangunan. Tidak hanya jenis material yang digunakan, suasana dalam bangunan juga menunjukan jalur sirkulasi yang ada di dalam bangunan dan juga perabotan yang digunakan.

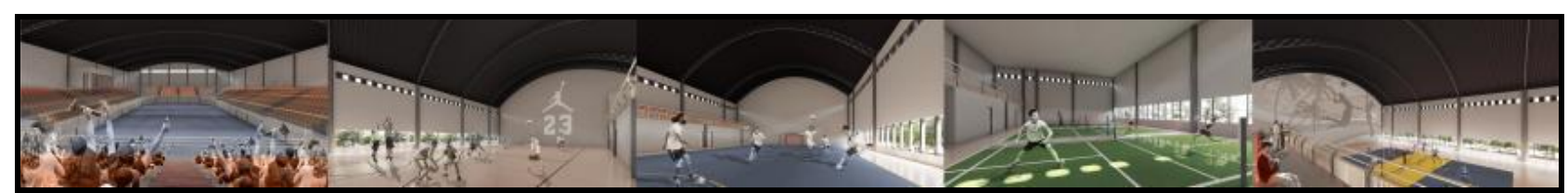

Gambar 16. Suasana Ruang Dalam Sport Center Universitas Tanjungpura

Sumber:` Penulis, 2020 


\section{Kesimpulan}

Sport Center Universitas Tanjungpura dirancang dengan tujuan menyediakan fasilitas olahraga yang dapat digunakan oleh civitas akademika Universitas Tanjungpura dan masyarakat sekitar untuk berolahraga maupun bersosialisasi.

Hasil perancangan adalah sebuah bangunan olahraga yang dapat menampung berbagai jenis olahraga seperti, olahraga bola basket, futsal, bola voli, beladiri, serta fasilitas fitness untuk menjaga kebugaran tubuh civitas akademika Universitas Tanjungpura maupun masyarakat sekitar.

Semoga tugas akhir ini dapat menjadi salah satu referensi jika seandainya Universitas Tanjungpura akan membangun sport center sebagai wadah untuk pembibitan atlet yang berpotensi mengembangkan kegiatan olahraga yang ada di Universitas Tanjungpura maupun Kota Pontianak.

\section{Ucapan Terima Kasih}

Ucapan terima kasih kepada Bapak Tri Wibowo Caesariadi ST., MT., selaku Dosen Pembimbing Utama; Bapak Affrilyno, S.T., M.Sc., selaku Dosen Pembimbing Pendamping; Ibu Bontor Jumaylinda br. Gultom, S.T., M.T., selaku Dosen Penguji Utama dan selaku Koordinator Proyek Tugas Akhir Tahun Akademik 2019/2020; Ibu Emilya Kalsum ST., MT., selaku Dosen Penguji Pendamping; serta kepada seluruh dosen dan staf Program Studi Arsitektur Universitas Tanjungpura yang telah memberikan ilmu yang bermanfaat selama ini.

\section{Daftar Acuan}

Banham, R (1978). Age of The Master: A Personal View of Modern Architecture. London: Architectural Press

Jones, J.C. (1992). Design Method (Second Edition). New York: Van Nostrand Reinhold

Kementerian Riset, Teknologi, dan Pendidikan Tinggi Republik Indonesia. (2015). Peraturan Menteri Riset, Teknologi, dan Pendidikan Tinggi Republik Indonesia Nomor 44 Tahun 2015 Bab VII pasal 32 ayat 1. Jakarta: Kementerian Riset, Teknologi, dan Pendidikan Tinggi Republik Indonesia

Nazir, M. (1988). Metodologi Penelitian. Jakarta: Ghalia Indonesia

Perrin, G.A. (1981). Design for Sport. Butterworths Design Series. England. Hal 65 s/d 69.

Sekretariat Negara Republik Indonesia. (2005). Undang-Undang Sistem Keolahragaan Nasional Nomor 3 tahun 2005 Bab VI pasal 17. Jakarta: Sekretariat Negara Republik Indonesia

Septiani T., Fitria, N. Hubungan antara resiliensi dengan stres pada mahasiswa sekolah tinggi kedinasan. Jurnal Penelitian Psikologi. 2016; 7(2): 59-76

Singh, A., Uijtdewilligen, L., Twisk, J.W.R, Michelen, W.V., \& Chinapaw, M.J.M. (2011). Physical Activity and Performance at School: A Systematic Review of the Literature Including a Methodological Quality Assessment. Amsterdam: Vrijie Universiteit 